\title{
PRZEMIANY NARODOWOŚCIOWE NA ZIEMI ŁOTEWSKIEJ W XX I NA POCZĄTKU XXI WIEKU
}

\author{
ETHNIC TRANSFORMATIONS ON THE LATVIAN \\ TERRITORY IN THE 20 ${ }^{\text {TH }}$ CENTURY \\ AND AT THE BEGINNING OF THE $21^{\text {ST }}$ CENTURY
}

\begin{abstract}
This paper presents demographic and ethnic transformations in the territory of Latvia. First, information is provided on the origins of the population of Latvian nationality. Then, ethnic composition of the population inhabiting the present-day Latvian territory at the end of the $19^{\text {th }}$ century is characterised. The basis for the respective statistical analysis is constituted by the results of the Russian census of 1897. This census showed, side by side with the Latvian population, also important German, Russian, Jewish, and Polish minorities. The subsequent part of the paper is devoted to the ethnic situation in the interwar period. Here, the census carried out in 1935 is the main source of information. Essential demographic transformations took place during World War II. The paper accounts for the war losses, which in ethnic terms had a selective character. Latvian Jews were exterminated, while the remaining groups also suffered great losses. Then, the paper takes up the subject of the demographic-ethnic situation during the post-war Soviet occupation and the existence of the Latvian Soviet Socialist Republic. In this period, numerous migrants from the farther-off territories of the Soviet Union moved to Latvia, these Russian-speaking migrants being primarily of Russian nationality. This resulted in the essential shift in the ethnic composition of the population in Latvia. The effects are reflected in the data from the Soviet censuses of
\end{abstract}

PIOTR EBERHARDT Instytut Geografii i Przestrzennego Zagospodarowania PAN, Warszawa E-mail: e.janko@twarda.pan.pl

CITATION: Eberhardt, P. (2017) Przemiany narodowościowe na ziemi totewskiej w XX i na początku XXI wieku. Sprawy Narodowościowe. Seria nowa, 2017(49). https://doi.org/10.11649/sn.1288

This work was supported by the author's own resources. No competing interests have been declared.

This is an Open Access article distributed under the terms of the Creative Commons Attribution 3.0 PL License (creativecommons.org/licenses/by/3.0/pl/), which permits redistribution, commercial and non-commercial, provided that the article is properly cited. (C) The Author(s) 2017.

Publisher: Institute of Slavic Studies, Polish Academy of Sciences 
1959 and 1989. The results of these censuses are subject to interpretation in the paper. The last part of the article is devoted to ethnic changes in the sovereign Latvian state. Statistical and substantive analysis was carried out using the census data of the year 2000, and the estimated data from the year 2014. The contemporary ethnic structure of the entire country and in individual provinces was established.

Key words: Latvia; Latvians; demography; nationalities

\section{Streszczenie}

W artykule przedstawiono przemiany demograficzno-etniczne na ziemi łotewskiej. We wstępie podano informacje o rodowodzie ludności narodowości łotewskiej. Następnie zaprezentowano i scharakteryzowano skład narodowościowy na współczesnym terytorium państwa łotewskiego w końcu XIX wieku. Podstawą analizy statystycznej były rezultaty spisu rosyjskiego z 1897 roku. Ujawnił on oprócz Łotyszy liczną mniejszość niemiecką, rosyjską, żydowską i polską. Kolejna część publikacji poświęcona jest sytuacji narodowościowej w okresie międzywojennym w niepodległym państwie łotewskim. Wykorzystano tu głównie spis przeprowadzony w 1935 roku. Poważne przeobrażenia demograficzne miały miejsce w latach II wojny światowej. Określono straty wojenne, które miały charakter selektywny w ujęciu narodowościowym. Przyniosły one eksterminację łotewskich Żydów oraz duże straty wśród pozostałych grup etnicznych. Dalsza część artykułu dotyczy sytuacji demograficzno-narodowościowej w okresie powojennej okupacji sowieckiej i istnienia Łotewskiej SRS. W tym czasie napłynęło na terytorium Łotwy wielu migrantów z głębi ZSRR. Była to ludność rosyjskojęzyczna, głównie narodowości rosyjskiej. Doprowadziło to do istotnej zmiany składu narodowościowego kraju. Odnotowały to spisy sowieckie z lat 1959 i 1989. Ich wyniki poddano interpretacji. Ostatnia część artykułu poświęcona jest zmianom narodowościowym zachodzącym już w suwerennym państwie łotewskim. Przeprowadzono analizę statystyczną i merytoryczną, korzystając z danych spisowych z 2000 roku oraz danych szacunkowych z 2014 roku. Określono współczesną strukturę narodowościową w skali całego kraju i wybranych prowincji.

Słowa kluczowe: Łotwa; Łotysze; demografia; narodowości

P roblematyka narodowościowa Łotwy, jednego z państw bałtyckich, była i jest bardzo złożona, tak w ujęciu czasowym jak i terytorialnym¹. Wyróżnia się swoją specyfiką geograficzną, polityczną, demograficzną i społeczną od sąsiedniej Litwy i Estonii. Naród łotewski jest też bardziej zróżnicowany językowo, religijnie i kulturowo od Litwinów i Estończyków. Aktualnie stosunki między Łotyszami i napływową ludnością rosyjską też są bardziej konfliktowe niż u jego północnego i południowego sąsiada. Z tego powodu wiedza o warunkach narodowościowych w Republice Łotewskiej ma nie tylko znaczenie poznawcze, ale również polityczne.

Początkowo ziemie łotewskie zamieszkiwały plemiona ugrofińskie (Estów, Kurów, Liwów) i dopiero w rezultacie stopniowej ekspansji z południa zostały one wyparte przez plemiona prałotewskie. Nie stworzyły one państwowości, gdyż w XIII wieku w wyniku interwencji zewnętrznej, w której wzięli udział Niemcy i Duńczycy, zostało utworzone państwo Kawalerów Mieczowych. Stało się to początkiem dominacji niemieckiej w zakresie języka i kultury. W następnych wiekach ziemie łotewskie były poddane ekspansji militarnej

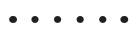

Kwestie narodowościowe Łotwy przedstawiono w monografii autora (Eberhardt, 1998). Analiza objęła okres do odzyskania przez Łotwę niepodległości, a ostatnim uwzględnionym spisem był spis sowiecki z 1989 r. Na łamach "Spraw Narodowościowych" ukazał się artykuł autora poświęcony jednej z prowincji łotewskich a mianowicie Łatgalii (Eberhardt, 2012). 
ze strony szwedzkiej, polskiej i rosyjskiej. Przez cały wiek XVIII i XIX prowincje totewskie stanowity integralną część Rosji, zaś wewnątrz kraju uprzywilejowaną pozycję ekonomiczną zajmowali niemieccy posiadacze ziemscy. Dopiero pod koniec XIX wieku pojawiło się pierwsze pokolenie inteligencji łotewskiej pochodzenia chłopskiego walczącej o równouprawnienie i prawo do języka łotewskiego. Przemiany społeczne, w tym rozwój oświaty, sprzyjały odrodzeniu narodowemu, które początkowo nie miało oblicza politycznego, lecz wyłącznie kulturowe. Miało ono swoją specyfikę regionalną, gdyż Łotwa dzieliła się na cztery historyczne prowincje, które odróżniały się tak pod względem społeczno-demograficznym, jak i etnograficzno-folklorystycznym². Była to Kurlandia (Kurzeme), Liwlandia (Vidzeme), Semigalia (Zemgale) i najbardziej peryferyjnie położona Łatgalia (Latgale) .

Pierwsze wiarygodne informacje o strukturze narodowościowej Łotwy dostarczył dopiero spis rosyjski z 1897 roku. Jest on oceniany przez specjalistów jako wiarygodny i umożliwia w miarę wierne odtworzenie składu etnicznego ludności zamieszkującej ówczesne ziemie łotewskie. Określił on dwie istotne cechy etniczne a mianowicie tzw. język ojczysty oraz wyznanie religijne. Były to kryteria właściwe. Deklaracja językowa świadczyła o przynależności do konkretnej grupy etnicznej, zaś wyznanie ujawniało w dużym stopniu rodowód kulturowy. Identyfikacja narodowościowa nie była jeszcze wówczas w warstwie chłopskiej wyklarowana. Natomiast język łotewski różnił się znacznie od języków używanych przez sąsiadów i w pełni wyróżniał ludność łotewską. Miał on swoje odrębności lingwistyczne, w zależności od prowincji, ale był prawidłowym wówczas wyznacznikiem narodowości łotewskiej. Podobnie było w przypadku innych grup narodowościowych (Niemców, Rosjan, Polaków, Litwinów). Jedynie pewna grupa Żydów deklarowała język rosyjski lub niemiecki jako swój język ojczysty. Przyjmując więc statystykę językową jako podstawę wnioskowania, możemy określić skład narodowościowy na ziemi łotewskiej w końcu XIX wieku. Na terytorium w przybliżeniu zawartym w granicach współczesnego państwa totewskiego skupiało się w 1897 roku - 1929,3 tys. mieszkańców różnej narodowości (Pervaia vseobshchaia perepis', 1899/1905):

\section{Tabela 1}

\begin{tabular}{|l|c|c|}
\hline \multicolumn{1}{|c|}{ Narodowość } & Liczba w tys. & \% ogółu ludności \\
\hline Łotysze & 1318,6 & 68,3 \\
\hline Rosjanie & 154,7 & 8,0 \\
\hline Niemcy & 137,0 & 7,1 \\
\hline Żydzi & 122,6 & 6,4 \\
\hline Białorusini & 79,7 & 4,1 \\
\hline Polacy & 65,2 & 3,4 \\
\hline Litwini & 24,4 & 1,3 \\
\hline Inne narodowości & 27,1 & 1,4 \\
\hline Razem & 1929,3 & 100,0 \\
\hline
\end{tabular}

\section{$\cdots \cdots \cdot$}

2 Zróżnicowanie etnograficzne Łotwy w ujęciu historyczno-terytorialnym opisano w książce: Pietkiewicz (1967).

3 Obecnie administracyjnie Łotwa jest podzielona na sześć regionów, które pomimo używanych dawnych nazw geograficznych, nie są w pełni zgodne z granicami czterech prowincji historycznych. Doszły dwa nowe regiony, a mianowicie Riga regions oraz Pierigas regions. Obejmują one głównie nadmorską część Liwlandii. Pierwszy z nich to wyodrębnione miasto Ryga, drugi niemający nazwy polskiej, to region położony nad Zatoką Ryską wokół Rygi i jest w zasadzie regionem metropolitalnym stołecznej Rygi. 
Trzy prowincje, Liwlandia, Semigalia i Kurlandia, cechowały się zbliżoną strukturą narodowościową ${ }^{4}$. Ludność łotewska stanowiła około 3/4 ogółu zaludnienia. Odmienna sytuacja miała miejsce $w$ Łatgalii. W tej prowincji Łotysze obejmowali jedynie 50,0\% zaludnienia. Liczni byli Rosjanie (15,5\%), Białorusini (13,2\%), Żydzi (12,7\%) i Polacy (6,2\%). W portowej Rydze zwiększał się stopniowo udział ludności łotewskiej. Do połowy XIX wieku dominowali tam Niemcy. Według spisu z 1897 roku ludność łotewska stanowiła już 45,0\% zaludnienia miasta, zaś Niemcy jedynie 23,9\%. W miarę upływu lat zaczęła się kształtować nieliczna inteligencja łotewska. Była ona początkowo antyniemiecka a nie antyrosyjska. W rezultacie rozwoju rzemiosła, a później przemysłu, pojawił się w miastach proletariat totewski.

Znacząca liczebność ludności rosyjskiej wynikała w dużym stopniu z faktu, że wliczono do niej żołnierzy służby czynnej oraz rosyjski korpus oficerski. Ze względu na duży garnizon w Rydze w mieście tym 16,1\% zaludnienia deklarowało narodowość rosyjską. We wschodniej Łotwie na terenach wiejskich skupiali się rosyjscy staroobrzędowcy uchodzący przed prześladowaniami z głębi Rosji. Ludność niemiecka miała charakter autochtoniczny. Składała się z wyższych warstw społecznych. Ziemiaństwo (z wyjątkiem Łatgalii) było narodowości niemieckiej, podobnie jak burżuazja i bogate mieszczaństwo. Zajmowali oni eksponowane stanowiska w administracji i armii carskiej. Mniejszość żydowska koncentrowała się w miastach, ajwięcej w Rydze i Dyneburgu.

Analizowany spis rosyjski ujawnił na ziemi totewskiej w 1897 roku Polaków w liczbie 65,2 tys. Najwięcej ich było w Łatgalii (Inflantach Polskich). W tej prowincji ziemiaństwo było polskie, ale zazwyczaj rodowodu niemieckiego ${ }^{5}$. W powiecie Iłukszta, należącym do guberni kurlandzkiej, oraz w sąsiednim powiecie dyneburskim na terenach wiejskich skupiała się chłopska ludność języka i narodowości polskiej. Przemieszana ona była z ludnością białoruską i totewską. Pochodzenie tej ludności było kwestią kontrowersyjną. Demografowie totewscy uważali ich za spolonizowanych Łotyszy, białoruscy i rosyjscy za skatolicyzowanych Białorusinów. Badacze polscy twierdzili, że była to ludność powstała ze zmieszania się ludności rodowodu łotewskiego i białoruskiego z napływową ludnością polską, która, podlegając wpływom polskojęzycznego Kościoła katolickiego oraz polskiego ziemiaństwa, przyjęła polską świadomość narodową.

Do wybuchu I wojny światowej ziemie łotewskie odznaczały się dużą dynamiką demograficzną, gdyż między 1897 a 1914 rokiem liczba ludności wzrosła z 1929,3 tys. do 2552,0 tys., czyli o 622,7 tys. Lata wojny przyniosły duże straty demograficzne ${ }^{6}$. Wynikały one z przeprowadzonej przez władze carskie totalnej ewakuacji oraz, w mniejszym stopniu, z działań wojennych. Pierwsze informacje powojenne dotyczące 1920 roku wykazały 1548,1 tys. Ubytek zaludnienia wyniósł około miliona mieszkańców. Skład narodowościowy uległ pewnym zmianom, co odnotowały dane statystyczne (Otra Tauta, 1925).

W spisie nie uwzględniono części dwóch rejonów, które zostały przyłączone po I wojnie światowej do Łotwy a mianowicie: putyłowskiego i przydrujskiego. Utworzono z nich łotewski powiat o nazwie Jaunlatgale. Był on zamieszkany w dużym stopniu przez Rosjan. Wpłynęło to na liczebność ludności rosyjskiej. W późniejszym czasie po włączeniu Łotwy do ZSRR, ten przygraniczny rejon został oderwany od Łotwy i do dzisiejszego dnia jest w składzie Rosji.

\section{- ....}

Kwestie nazewnictwa polsko-łotewskiego wyjaśniono w studium M. Buczyńskiego (1993).

Czołowy przedstawiciel tego środowiska opisał życie polskiego ziemiaństwa w dawnych Inflantach Polskich (Manteuffel, 2007).

6 W latach I wojny światowej, zwłaszcza w krótkim okresie powojennym, ważyły się losy polityczne Łotwy. Destabilizacja w Rosji umożliwiła uzyskanie przez Łotwę niepodległości (Paluszyński, 1999). 


\section{Tabela 2}

\begin{tabular}{|l|c|c|}
\hline \multicolumn{1}{|c|}{ Narodowość } & Liczba w tys. & \% ogółu ludności \\
\hline Łotysze & 1159,4 & 74,9 \\
\hline Rosjanie & 91,5 & 5,9 \\
\hline Żydzi & 79,4 & 5,1 \\
\hline Białorusini & 66,2 & 4,3 \\
\hline Niemcy & 58,1 & 3,7 \\
\hline Polacy & 52,2 & 3,4 \\
\hline Litwini & 25,5 & 1,6 \\
\hline Inne narodowości & 15,8 & 1,1 \\
\hline Razem & 1548,1 & 100,0 \\
\hline
\end{tabular}

Lata międzywojenne odznaczały się stabilnością społeczno-gospodarczą. Nie udało się w pełnym zakresie odrobić demograficznych strat wojennych. Były one za wysokie. Niemniej występował stały sukcesywny wzrost zaludnienia. Władze łotewskie zmierzały do konsolidacji kraju i obniżenia roli mniejszości narodowych. Preferowani byli Łotysze. Stopniowo ulegała marginalizacji istniejąca przez stulecia dominacja elementu niemieckiego a w końcu XIX wieku administracji rosyjskiej. Ustawodawstwo prawne nowej republiki zapewniało warunki swobodnego kultywowania odrębności etnicznych. Niestety w praktyce dochodziło do dyskryminacji. Zmierzano do asymilacji mniejszości narodowych i wykreowania państwa narodowego ${ }^{7}$. Niemniej, do połowy lat 30. funkcjonowało szkolnictwo i oświata w językach pozałotewskich. W kolejnych spisach uwzględniano kryteria etniczne i określano liczebność poszczególnych grup narodowościowych i religijnych" Można to wykazać na podstawie spisu przeprowadzonego w 1935 roku, który ujawnił nowy skład narodowościowy Republiki Łotewskiej (Certurtă Tauta Skaitisana Latvija, 1937):

\section{Tabela 3}

\begin{tabular}{|l|c|c|}
\hline \multicolumn{1}{|c|}{ Narodowość } & Liczba w tys. & \% ogółu ludności \\
\hline Łotysze & 1472,6 & 75,5 \\
\hline Rosjanie & 206,5 & 10,6 \\
\hline Żydzi & 93,4 & 4,8 \\
\hline Niemcy & 62,1 & 3,2 \\
\hline Polacy & 48,9 & 2,5 \\
\hline Białorusini & 26,9 & 1,4 \\
\hline Litwini & 22,9 & 1,2 \\
\hline Inne narodowości & 17,2 & 0,8 \\
\hline Razem & 1950,5 & 100,0 \\
\hline
\end{tabular}

7 Wiele informacji o funkcjonowaniu państwa łotewskiego zawiera publikacja Łossowski (1990).

Polscy badacze w okresie międzywojennym obserwowali i analizowali stosunki narodowościowe na Łotwie. Głównie zajmowali się sytuacją ludności polskiej, ale przy okazji także polityką narodowościową państwa totewskiego wobec innych mniejszości oraz oceniali wiarygodność statystyki łotewskiej (Cynarski, 1925; Maliszewski, 1922; Różycki, 1930; Sworakowski, 1934). 
Na podstawie spisu z lat 1920 i 1935 można określić pewne kierunki przemian narodowościowych. Liczba ludności łotewskiej wyraźnie wzrosła z 1159,4 tys. do 1472,6 tys.. Było to wynikiem przyrostu naturalnego, ale również procesów asymilacyjnych, jak i pewnym zafałszowaniem statystycznym. Znacznie wzrosła liczebność Rosjan spowodowana wspomnianymi zmianami granicznymi oraz napływem tzw. białej emigracji. Niektóre mniejszości ulegały wyraźnej redukcji liczebnej. Na przykład liczba Białorusinów zmniejszyła się z 66,2 tys. do 26,9 tys. (było to przykładem deformacji statystycznej), Polaków zaś z 52,2 tys. do 48,9 tys. Natomiast liczba Żydów wzrosła z 79,4 tys. do 93,4 tys. Ważniejsze były przeobrażenia w ujęciu terytorialnym. We wszystkich prowincjach, powiatach i miastach wzrósł udział ludności łotewskiej. Zwłaszcza jest to widoczne w porównaniu do stanu sprzed I wojny światowej. Można tu podać przykładowo, że w stołecznej Rydze udział ludności łotewskiej wzrósł w 1935 roku do poziomu 63,0\% (w 1897 r. - 45,0\%), zaś niemieckiej obniżył się do stanu 10,0\% (1897 r. - 23,9\%), rosyjskiej do poziomu 7,3\% (1897 r. - 16,1\%). Poza Łotyszami wzrósł w Rydze jedynie odsetek ludności deklarującej narodowość żydowską (do 11,3\%). Była ta ewolucja przeobrażeń narodowościowych rezultatem celowej działalności władz łotewskich (z wyjątkiem wzrostu liczby Żydów), które realizowały zaprogramowaną akcję łotywizacji i ograniczania znaczenia mniejszości narodowych, głównie niemieckiej i rosyjskiej. Przyniosła ona oczekiwane skutki i pod koniec okresu międzywojennego zaczęło się kształtować narodowe państwo łotewskie.

Stosunek władz centralnych do mniejszości polskiej był niekonsekwentny. Z jednej strony w ramach przyjętej polityki zmierzano do asymilacji ludności polskiej. Z drugiej zaś, aby utrzymać dobre stosunki z Polską, tolerowano istnienie szkół i stowarzyszeń polskich. W ramach realizowanej reformy rolnej nastąpiła parcelacja wielkiej własności ziemskiej. Uderzyła ona w niemieckich i polskich posiadaczy ziemskich. Zmierzano do utworzenia bogatych łotewskich gospodarstw chłopskich. Akcja ta zakończyła się powodzeniem i polskie ziemiaństwo zostało spauperyzowane. Przyniosto to efekty nie tylko społeczne i ekonomiczne, ale również polityczne i narodowe.

Okres międzywojenny odegrał olbrzymią rolę w tworzeniu się nowoczesnego narodu łotewskiego. Istnienie własnego państwa, zapewnienie językowi łotewskiemu po raz pierwszy w historii uprzywilejowanej pozycji, rozwój literatury i kultury narodowej przyniósł niebagatelną rolę państwowotwórczą i ukształtował świadomość narodu łotewskiego. Można nawet stwierdzić, że bez tego dwudziestolecia naród łotewski nie mógłby przetrwać późniejszej długotrwałej okupacji sowieckiej i po rozpadzie ZSRR reaktywować w sposób skuteczny i sprawny nowe suwerenne państwo. Pamięć o własnym stosunkowo bogatym i dobrze zorganizowanym państwie była tą wielką wartością moralną, która umożliwiła w końcu XX wieku restytucję niezależnej Republiki Łotewskiej.

Zawarcie paktu niemiecko-rosyjskiego z 23 VIII 1939 roku przesądziło los Łotwy, która dostała się do sowieckiej strefy wpływów. Faktycznym potwierdzeniem tego aktu było utworzenie 5 VIII 1940 roku Łotewskiej SRR. Rozpoczęła się okupacja sowiecka, która przyniosła nie tylko doniosłe konsekwencje polityczne ale i demograficzno-etniczne. Bezpośrednio po zajęciu kraju rozpoczęły się represje i celowe prześladowania elity narodu łotewskiego. Równocześnie rozpoczęły się deportacje w głąb ZSRR faktycznych i potencjalnych przeciwników nowego systemu okupacyjnego. Władze sowieckie dokonały również mobilizacji do Armii Czerwonej. Na mocy porozumienia między Rzeszą Niemiecką a ZSRR rozpoczęła się repatriacja ludności niemieckiej. Do Niemiec wyjechało w 1940 roku łącznie 63,0 tys. łotewskich Niemców. Przyniosło to wszystko poważne straty demograficzne. Agresja niemiecka na ZSRR zmieniła diametralnie sytuację polityczną. Zmiana 
okupantów przyniosła dalsze dotkliwe straty ludnościowe. Eksterminacja ludności żydowskiej zakończyła się prawie pełnym jej unicestwieniem. Zginęło około 90 tys. łotewskich Żydów. Władze niemieckie utworzyły tzw. legion łotewski liczący około 60 tys., który brał udział w walkach na froncie wschodnim. Duża liczba Łotyszy była wywieziona na roboty do Niemiec. Zbliżanie się Armii Sowieckiej wywołało exodus na zachód miejscowej ludności obawiającej się nowych represji. Łącznie kilkaset tysięcy mieszkańców Łotwy zginęło lub było zmuszonych opuścić kraj. Ocenia się, że w wyniku II wojny światowej liczba ludności narodowości łotewskiej zmniejszyła się o około 200,0 tys. osób. Dla narodu nielicznego były to straty bolesne, które zaważyły na bilansie demograficznym kraju9 .

Ponowne odtworzenie władzy sowieckiej w końcu 1944 roku zainicjowało nowe ruchy migracyjne. Rozpoczęły się kolejne represje i nowe deportacje. Objęły między innymi mieszkańców wsi, którzy sabotowali forsowaną wówczas akcję kolektywizacji10. Włączenie kraju do ZSRR otworzyło granice przed migrantami z innych republik sowieckich, w tym głównie Rosjan. Procesy te były stymulowane w sposób celowy przez okupacyjne władze sowieckie, które nie miały zaufania do miejscowej ludności. Utworzenie nowego aparatu administracyjnego i partyjnego wymagało nowych kadr. Rozpoczęła się industrializacja. Wymagała ona zatrudnienia specjalistów, których na miejscu brakowało. Należy zaznaczyć, że Łotwa była krajem atrakcyjnym dla migrantów rosyjskich. Wyższy standard życia, łatwość uzyskana mieszkania oraz pracy w przemyśle i rolnictwie stwarzał obiektywne przesłanki do podejmowania decyzji migracyjnej. Absolwenci szkół i uczelni łotewskich uzyskiwali z kolei nakazy pracy poza granicami republiki. Było to powodem przeobrażeń demograficzno-etnicznych zmierzających do ewolucyjnej zmiany struktury narodowościowej. Działo się to w okresie powojennej kompensacji demograficznej. Stosunkowo wysoka dzietność, przy malejącej umieralności, przyniosła znaczny przyrost naturalny, który częściowo zrekompensował straty wojenne.

Pierwsze powojenne ścisłe dane statystyczne o liczbie ludności i jej składzie etnicznym posiadamy z sowieckiego spisu powszechnego w 1959 roku. Można go przytoczyć wiernie, gdyż określił on w sposób w miarę wiarygodny narodowość każdego mieszkańca Łotwy (/togi, 1963):

\section{Tabela 4}

\begin{tabular}{|l|c|c|}
\hline \multicolumn{1}{|c|}{ Narodowość } & Liczba w tys. & \% ogółu ludności \\
\hline Łotysze & 1297,9 & 62,0 \\
\hline Rosjanie & 556,5 & 26,6 \\
\hline Białorusini & 61,6 & 2,9 \\
\hline Polacy & 59,8 & 2,9 \\
\hline Żydzi & 36,6 & 1,7 \\
\hline Litwini & 32,4 & 1,5 \\
\hline Ukraińcy & 29,4 & 1,4 \\
\hline Niemcy & 1,6 & 0,1 \\
\hline Inne narodowości & 17,7 & 0,9 \\
\hline Razem & 2093,5 & 100,0 \\
\hline
\end{tabular}

9 Problematyka prześladowań ludności łotewskiej przedstawiona jest w opracowaniu: J. Korzenia (J. Roszkowskiego) (Korzeń, 1987).

10 Do początku lat 50. wysiedlono z Łotwy w głąb ZSRR około 50,0 tys. deportowanych. O skali i cyklach czasowych tych akcji petną informacje zawiera monografia polskich badaczy z Wrocławia (Ciesielski, Hryciuk, \& Srebrakowski, 2004). 
Między ostatnim spisem przedwojennym a pierwszym powojennym wystąpity istotne przemiany narodowościowe. Przy analizie przedstawionych danych statystycznych dla 1959 roku należy uwzględnić nieznaczne, wspomniane już, różnice terytorialne, wynikające z utraty przez Łotwę niewielkich terenów przygranicznych, w których mieszkało kilkadziesiąt tysięcy mieszkańców, głównie narodowości rosyjskiej. Nie odgrywało to większego znaczenia statystycznego. Liczba ludności na rozpatrywanym terytorium łotewskim wzrosła między 1935 a 1959 rokiem o 143,0 tys. Z jednej strony było to rezultatem przyrostu naturalnego w latach 1935-1940 i 1946-1959 oraz dodatniego bilansu migracyjnego, wynikającego z przybycia na Łotwę obywateli sowieckich z innych republik. Zrekompensowało to poważne straty wojenne. W analizowanym czasie liczba obywateli narodowości łotewskiej zmalała o 174,7 tys., natomiast liczebność osób deklarujących narodowość rosyjską wzrosła o 350,0 tys. Równocześnie zwiększyła się populacja innych mniejszości rodowodu słowiańskiego. Między innymi pojawiła się liczna mniejszość ukraińska (29,4 tys.), nastąpił przyrost liczby Białorusinów (o 34,7 tys.). Byli to powojenni migranci ekonomiczni, dla których Łotwa była atrakcyjnym miejscem zamieszkania. Łącznie Rosjanie, Białorusini i Ukraińcy zwiększyli swoją liczebność między 1935 a 1959 rokiem o 414,0 tys. Trzy wymienione grupy narodowościowe obejmowały w 1935 roku 12,0\%, zaś w 1959 roku już 30,9\% zaludnienia kraju. Odbywało się to kosztem Łotyszy, których udział w ludności kraju zmalał z $75,5 \%$ do $62,0 \%$. Było to jednak dopiero początkiem zmian, które miały w przyszłości jeszcze bardziej zdetronizować łotewską ludność autochtoniczną na rzecz rosyjskojęzycznych przybyszy. Procesy te zachodziły na obszarze całego kraju w sposób nierównomierny, gdyż intensywność ich była o wiele większa w miastach niż na terenach wiejskich. Te ostatnie, z wyjątkiem wschodnich obszarów przygranicznych, zachowały oblicze łotewskie. Natomiast w większych miastach udział napływowej ludności rosyjskiej był coraz wyższy i zaczął zmieniać oblicze narodowościowo-językowe ośrodków i obszarów o wyższym stopniu zurbanizowania.

Lata wojny przyniosły kres istnienia mniejszości niemieckiej na ziemi łotewskiej ${ }^{11}$. Od średniowiecza do połowy XIX wieku w pełni dominowała ona politycznie i ekonomicznie. W drugiej połowie XIX wieku władze carskie zaczęły ograniczać ich supremację polityczną. Nadal jednak większa część użytków rolnych oraz przemysłu była w rękach miejscowych rodzin niemieckich. Dopiero w okresie międzywojennym, w wyniku reformy rolnej i celowej polityki finansowej państwa totewskiego, ich pozycja finansowa stopniowo ulegała marginalizacji. W pierwszej fazie wojny $w$ wyniku porozumienia niemiecko-sowieckiego miała miejsce wspomniana repatriacja Niemców do III Rzeszy. Późniejsze lata wojny przyniosły pełną zagładę mniejszości niemieckiej. Resztki tej ludności uciekły wraz z cofającym się Wermachtem. Spis z 1959 roku ujawnił na Łotwie zaledwie 1,6 tys. Niemców. Bardziej tragiczny był los Żydów, którzy poddani byli totalnej eksterminacji. Po wojnie duża liczba Żydów wróciła ponownie na Łotwę. Byli to uchodźcy ewakuowani przez władze sowieckie, a jeszcze dawniej przez władze carskie. Wielu migrantów żydowskich napłynęło po wojnie na Łotwę, głównie do Rygi, szukając lepszych warunków egzystencji niż w biedniejszej Rosji. Mniejszość polska przetrwała lata wojny. Nie mając przedwojennego obywatelstwa polskiego, nie podlegali repatriacji do Polski. Statystycznie ich liczebność między rokiem 1935 a 1959 wzrosła, ale wynikało to głównie z tendencyjności przedwojennego spisu totewskiego.

11 Sytuacja demograficzno-społeczna mniejszości niemieckiej na Łotwie została omówiona w opracowaniu Topij (1998). 
Z przedstawionych informacji wynika, że wojna, a następnie przywrócenie okupacji sowieckiej miały duży wpływ na sytuację demograficzno-etniczną Łotwy. Napływ żywiołu słowiańskiego, głównie Rosjan, oraz tępienie objawów wszelkiej ideologii narodowej nawiązującej do idei własnego państwa miało na celu zniewolenie narodu łotewskiego. Traktowano wszelkie aspiracje niepodległościowe jako wyraz poglądów nacjonalistycznych, wręcz faszystowskich, podlegających represjom. Zwalczanie ich wpłynęło na pozycję polityczną narodu łotewskiego pozbawionego we własnym kraju suwerenności i przysługującym im praw obywatelsko-narodowych. Intensywne procesy sowietyzacji w wymiarze politycznym i kulturowym doprowadzały w sposób nieunikniony do przemian świadomościowo-mentalnych. Należy jednak zaznaczyć, że nie dotyczyło to języka łotewskiego, który miał pełne prawa obywatelskie. Istniała oświata i szkolnictwo w języku łotewskim a nawet wspierano ludowy folklor łotewski i literaturę łotewską, jeżeli była wierna pryncypiom ustrojowym. Coraz większy jednak udział ludności rosyjskojęzycznej stopniowo zmieniał oblicze demograficzne kraju.

Procesy sowietyzacji i rusyfikacji były najbardziej zaawansowane w większych ośrodkach miejskich, zwłaszcza w Rydze. W mieście tym w 1935 roku odsetek ludności łotewskiej wynosił 60,3\%, zaś rosyjskiej 7,8\%. Spis sowiecki z 1959 roku ujawnił, że w mieście skupia się 44,7\% ludności łotewskiej i 39,4\% ludności narodowości rosyjskiej. Doliczając jednak inne narodowości używające języka rosyjskiego, ta mała przewaga Łotyszy miała już charakter pozorny. Ludność rosyjska była młodsza wiekowo, co też miało znaczenie nie tylko demograficzne.

Następne spisy sowieckie odbyły się w latach 1970, 1979 i 1989. W dalszej analizie rozpatrzymy jedynie wyniki tego ostatniego spisu. Odbył się on w ostatniej fazie istnienia ZSRR i u progu ukonstytuowania się niepodległego państwa łotewskiego. Wykazał on na terytorium Łotewskiej SRS w 1989 roku 2666,6 tys. mieszkańców. Między dwoma spisami (1959 i 1989), czyli w ciągu 30 lat, w wyniku nadwyżki urodzeń nad liczbą zgonów oraz dodatniego salda migracyjnego miał miejsce przyrost rzeczywisty w wysokości 573,1 tys. Zgodnie z przyjętą konwencją na podstawie tego ostatniego spisu sowieckiego można określić skład narodowościowy ówczesnej Łotewskiej SRS (Natsional'nyı̆ sostav naseleniia, 1991):

\section{Tabela 5}

\begin{tabular}{|l|c|c|}
\hline \multicolumn{1}{|c|}{ Narodowość } & Liczba w tys. & \% ogółu ludności \\
\hline Łotysze & 1387,8 & 52,0 \\
\hline Rosjanie & 905,5 & 34,0 \\
\hline Białorusini & 119,7 & 4,5 \\
\hline Ukraińcy & 92,1 & 3,5 \\
\hline Polacy & 60,4 & 2,3 \\
\hline Litwini & 36,4 & 1,3 \\
\hline Żydzi & 22,9 & 0,9 \\
\hline Niemcy & 3,8 & 0,1 \\
\hline Inne narodowości & 38,0 & 1,4 \\
\hline Razem & 2666,6 & 100,0 \\
\hline
\end{tabular}


W okresie międzyspisowym (1959-1989) liczba ludności łotewskiej nieznacznie się zwiększyła (o 89,9 tys.). W tym samym czasie liczba Rosjan powiększyła się o 349,0 tys. Doprowadziło to do wzrostu udziału ludności rosyjskiej z 26,6 do 34,0\%. W rezultacie tego odmiennego tempa przyrostu demograficznego nastąpił ubytek procentowy ludności łotewskiej z 62,0 do 52,0\%. W żadnym z trzech krajów bałtyckich nie było tak szybkich zmian proporcji wielkościowych między ludnością miejscową a napływową ludnością rosyjską. Łotysze w końcu lat 80. XX stulecia zaledwie przekraczali połowę zaludnienia kraju. Natomiast Rosjanie z rosyjskojęzycznymi Ukraińcami i Białorusinami stanowili w 1989 roku 42,0\% ogółu ludności Łotewskiej SRS. Kraj stopniowo nabierał charakteru kolonialnego, gdzie język metropolii funkcjonował jako język nadrzędny i oficjalny, zaś na peryferiach życia istniał język ludności tubylczej. Procesy rusyfikacji nie wynikały ze zmiany poczucia narodowego u Łotyszy, lecz z przemian demograficznych, wynikających ze stopniowego zwiększania się liczby ludności rodowodu niełotewskiego. Można stwierdzić, że nie tyle rusyfikowali się Łotysze, ile rusyfikował się kraj, w którym coraz bardziej dominował język ludności nieautochtonicznej. W stałej konfrontacji między językiem łotewskim i rosyjskim, ten drugi uzyskiwał coraz większe znaczenie. Wynikało to nie tylko z prowadzenia odgórnej polityki, lecz z powstania obiektywnych warunków, w których język rosyjski stawał się najbardziej użyteczny. Działo się to, o czym już mówiono przy teoretycznym równouprawnieniu wszystkich języków. w tym łotewskiego Nikt nie był dyskryminowany za posługiwanie się językiem łotewskim. Niemniej, realne warunki doprowadziły do sytuacji, w których język łotewski był coraz bardziej marginalizowany, zaś mieszkający na Łotwie Rosjanie zazwyczaj go nie znali. W ogólnym obiegu społecznym dominował wyłącznie język rosyjski. O sile dwóch języków świadczy fakt, że mniejszości narodowe takie jak Polacy, zatracając własny język, przyjmowali język rosyjski a nie łotewski.

Sowietyzacja i rusyfikacja miały wyraźną specyfikę terytorialną. Dominacja rosyjska obejmowała najpierw duże miasta, następnie mniejsze, a w końcu docierała do każdego zakątka kraju. Stołeczna Ryga jest tu modelowym przykładem istniejącej ewolucji narodowościowej. Liczba ludności rosyjskiej w 1935 roku wynosiła 28,3 tys. (7,3\% zaludnienia), 1959 roku 228,7 tys. (39,4\%), 1989 roku 430,6 tys. (47,3\%). W tymże roku 1989 Łotysze w Rydze obejmowali 36,5\% zaludnienia miasta. W niektórych innych miastach (np. Dyneburgu) udział ludności totewskiej był znacznie niższy.

Przy zachowaniu mocno utrwalonych tendencji przemian demograficznych zaczęła się pojawiać groźba utraty przez Łotyszy przewagi liczebnej i stania się mniejszością we własnym kraju. Oceniając istniejące trendy przemian, można sądzić, że oderwanie się od wspólnoty politycznej z Rosją (ZSRR) oraz odzyskanie suwerenności przyszło w ostatnim momencie. Należy przypuszczać, że przetrwanie w niezmienionej postaci Związku Sowieckiego jeszcze przez kilkadziesiąt lat doprowadziłoby do pełnej katastrofy narodowej. Łotysze staliby się mniejszością we własnym kraju i jakiekolwiek radykalne zmiany geopolityczne byłyby już niemożliwe lub bardzo trudne do przeprowadzenia.

Restytucja niepodległego państwa łotewskiego przyniosła poważne konsekwencje nie tylko polityczne, ale również demograficzno-etniczne. W odróżnieniu od tych pierwszych, które zachodzą w sposób rewolucyjny, zmiany w zakresie stosunków narodowo-językowych, pomijając konflikty militarne i przymusowe przesiedlenia, mają zazwyczaj charakter ewolucyjny i ulegają stopniowym przemianom w wymiarze generacyjnym. W przypadku Łotwy zmiany polityczne były raptowne i wynikały z przyczyn zewnętrznych. Po zmianie tych uwarunkowań geopolitycznych nastąpiła zmiana statusu politycznego Łotyszy i Rosjan. Ci pierwsi zajęli pozycję dominującą i uprzywilejowaną na scenie politycznej Łotwy. Natomiast 
ludność rosyjska, żyjąc w izolacji w stosunku do otaczającego ją społeczeństwa łotewskiego, znalazła się po odzyskaniu przez Łotwę niepodległości w bardzo trudnych warunkach socjalnych i ekonomicznych. Straciła bezpowrotnie wpływ na kierowanie państwem. Nie znając języka łotewskiego stała się elementem obcym i niepożądanym. Miejscowi Rosjanie poczuli się dyskryminowani i traktują to jako zamach na swoje prawa obywatelskie. W takiej sytuacji stanęli przed niełatwym dylematem. Pierwsza opcja wiązała się z wyjazdem do Rosji, co nie było łatwe do zrealizowania. Zostanie na miejscu wymagało dostosowania się do nowych warunków i przyjęcia statusu typowej mniejszości narodowej. Ze względu na różnice językowe i kulturowe wtopienie się w społeczeństwo łotewskie nie mogło być łatwe. Nałożyły się na to trudne warunki ekonomiczne. Zmiana ustroju wywołała upadek wielu przedsiębiorstw przemysłowych. Rosyjska kadra kierownicza i techniczna utraciła pracę. Wielu czynnych i emerytowanych oficerów sowieckich z dezaprobatą lub wrogością odniosło się do nowej rzeczywistości politycznej. Wiele tysięcy rodzin rosyjskich, ukraińskich czy białoruskich postanowiło opuścić kraj. Podjęcie decyzji migracyjnych było uzależnione od możliwości wymiany lub sprzedaży czy kupna mieszkania. Zmieniły się kierunku migracyjne i dotychczasowe saldo dodatnie zmieniło się na ujemne, gdyż jedynie niewielu Łotyszy wróciło z innych republik postsowieckich. Równocześnie zmieniły się na niekorzyść tendencje w ruchu naturalnym ludności. Obniżyła się stopa urodzeń oraz wzrosła umieralność. Przyrost naturalny zmienił się w ubytek naturalny. Procesy depopulacyjne utrwality się i zaczęły przynosić niekorzystne konsekwencje nie tylko demograficzne.

Władze totewskie, obawiając się destrukcyjnej działalności ludności rosyjskojęzycznej, która nie ukrywała swej dezaprobaty wobec powstania niepodległej Łotwy, uchwaliły ustawę o obywatelstwie. Według jej ustaleń obywatelstwo łotewskie uzyskali automatycznie jedynie potomkowie mieszkańców przedwojennej Łotwy. Ustawodawstwo to zostało bardzo silnie skrytykowane przez władze Federacji Rosyjskiej, która uzyskała w tej sprawie poparcie organizacji międzynarodowych. W rezultacie presji ustawa o obywatelstwie została częściowo zliberalizowana. Między innymi przyjęto zobowiązanie, że Rosjanie spetniający odpowiednie wymogi stopniowo uzyskają prawo do naturalizacji. Przeciwstawiały się temu rozwiązaniu totewskie ugrupowania prawicowe. Rozwiązanie tej kwestii wiąże się bowiem z uzyskaniem praw wyborczych i potencjalną możliwością powstania w parlamencie łotewskim licznego nacjonalistycznego ugrupowania rosyjskiego, zmierzającego do demontażu państwa. Początkowo zamierzano wprowadzić niewielkie kwoty roczne i przyznawanie obywatelstwa łotewskiego jedynie po zdaniu egzaminu z języka i historii Łotwy. Po długim dyskursie politycznym w dużym stopniu ta sprawa została w połowie 1998 roku rozwiązana. Odbyło się ogólnonarodowe referendum, które zdecydowało o przyznaniu dużych ułatwień przy uzyskiwaniu obywatelstwa łotewskiego przez ludność rosyjskojęzyczną. Pomimo to nadal istnieje spora populacja ludności pozbawionej obywatelstwa, która działa destabilizująco na funkcjonowanie państwa.

Niestabilne warunki polityczne, społeczne i ekonomiczne wpłynęły na sytuację demograficzną. Nałożyły się na to duże ruchy migracyjne, które miały charakter selektywny, gdyż przede wszystkim objęły ludność rosyjskojęzyczną, w tym głównie rosyjską. Z tego powodu z dużą niecierpliwością oczekiwano wyników pierwszego spisu ludności, już w suwerennym państwie totewskim. Zgodnie z przewidywaniami wyniki spisu wykazały znaczne zmniejszenie się zaludnienia kraju. Zrealizowany spis 2000 roku wykazał na terytorium państwa łotewskiego 2377,4 tys. mieszkańców, czyli ubytek między 1989 a 2000 rokiem wyniósł 289,2 tys. Spis określit również strukturę narodowościową ludności Republiki Łotewskiej (Latvijas Statisticas Gadagrămata, 2014): 


\section{Tabela 6}

\begin{tabular}{|l|c|c|}
\hline \multicolumn{1}{|c|}{ Narodowość } & Liczba w tys. & \% ogółu ludności \\
\hline Łotysze & 1370,7 & 57,6 \\
\hline Rosjanie & 703,2 & 29,6 \\
\hline Białorusini & 97,1 & 4,1 \\
\hline Ukraińcy & 63,6 & 2,7 \\
\hline Polacy & 59,5 & 2,5 \\
\hline Litwini & 33,4 & 1,4 \\
\hline Żydzi & 10,4 & 0,4 \\
\hline Niemcy & 3,5 & 0,1 \\
\hline Inne narodowości & 36,0 & 1,6 \\
\hline Razem & 2377,4 & 100,0 \\
\hline
\end{tabular}

Rezultaty spisu zrealizowanego w 2000 roku ujawnity zmianę dotychczas mocno utrwalonych tendencji w zakresie składu narodowościowego Łotwy i dynamiki poszczególnych grup etnicznych. Nieustannie po wojnie i włączeniu Łotwy do Związku Sowieckiego wzrastała liczba ludności rosyjskiej oraz rosyjskojęzycznej. Wyraził się ten trend zarówno w wymiarze liczb absolutnych jak i odniesionych do udziału w procentowym zaludnieniu kraju. Po zmianach politycznych i uzyskaniu przez Łotyszy suwerenności sytuacja diametralnie się zmieniła. Nastąpiło stopniowe umocnienie żywiołu łotewskiego we własnym państwie. Na skutek wspomnianych procesów depopulacyjnych liczba ludności narodowości łotewskiej uległa $w$ analizowanym okresie nieznacznemu zmniejszeniu (o 17,1 tys. czyli o 1,2\%), to w tym samym czasie między 1989 a 2000 rokiem liczba ludności narodowości rosyjskiej zmalała o 202,3 tys., czyli aż o 22,3\%. Przyniosło to w efekcie wzrost udziału Łotyszy w zaludnieniu kraju z 52,0\% do 57,6\%, tzn. o 5,6 pkt. procentowego, przy równoczesnym obniżeniu się odsetka Rosjan z 34,0\% do 29,6\%. Podobna sytuacja miała miejsce w przypadku napływowej ludności ukraińskiej i białoruskiej, która nie potrafiła się odnaleźć w nowych warunkach politycznych. Zazwyczaj słabo znała język łotewski i wybrała wariant migracyjny. Udział procentowy tych trzech grup słowiańskich zmniejszył się z 42,0\% (1989) do 36,4\% (2000). Był to udział nadal niezmiernie wysoki, ale wszelkie przesłanki wskazywały, że się będzie obniżał. Potwierdziły to późniejsze dane statystyczne.

Natomiast trzecia grupa słowiańska, mianowicie Polacy, przetrwali te zawirowania polityczne bez specjalnych perturbacji. Spis sowiecki z 1989 roku odnotował w Łotewskiej SRR - 60,4 tys., zaś spis łotewski z 2000 roku wykazał obecność 59,5 tys. Polaków Wyjaśnienie jest proste, W odróżnieniu od większości napływowych Rosjan, Ukraińców i Białorusinów ludność polska miała charakter autochtoniczny i ich przodkowie byli w okresie międzywojennym obywatelami państwa łotewskiego. Repatriacja zaś do Polski nie była brana pod uwagę ani przez stronę totewską, ani polską.

Następne lata związane już z początkiem XXI wieku były kontynuacją przemian demograficzno-etnicznych wywołanych rewolucyjnymi przeobrażeniami zainicjowanymi upadkiem komunizmu, rozpadem ZSRR i odrodzeniem państwowości łotewskiej. Zakończyły się masowe wyjazdy ludności rosyjskojęzycznej. W pierwszej spontanicznej fazie objęły one ponad 100 tys. migrantów. Większość, która postanowiła pozostać, musiała w dużej mierze pogodzić się z zaistniałą sytuacją geopolityczną i ze zrozumiałymi oporami zmusze- 
ni byli zaakceptować przynależny im status licznej, ale jednak tylko mniejszości narodowej. Zdali sobie sprawę, że powrót do rzeczywistości sowieckiej jest całkowicie nierealny. Wielu z nich oceniło ich standard życia jako wyższy niż w sąsiedniej Rosji. Włączenie Łotwy do Unii Europejskiej otworzyło im możliwości okresowych lub stałych wyjazdów do pracy w krajach zachodnioeuropejskich. Pojawiło się równocześnie nowe zjawisko psychologiczne, które dotyczyło dużej grupy ludności żyjącej na styku narodowości rosyjskiej i łotewskiej. Głównie dotyczyło to małżeństw mieszanych i ich dzieci. W okresie sowieckim zazwyczaj ci ludzie wtapiali się w społeczność rosyjskojęzyczną. W sytuacji utrwalania się niepodległego bytu nowego państwa, ta mieszana populacja o nie w pełni skrystalizowanej narodowości w coraz większym stopniu zaczęła przyjmować opcję prołotewską. Dawało im to większe profity ekonomiczne i prestiżowe.

Nie oznaczało to, że sytuacja demograficzna stawała się bardziej pomyślna. Trudne warunki ekonomiczne wpłynęły negatywnie na rozrodczość i poziom urodzeń. Przyjęły te współczynniki ruchu naturalnego wyjątkowo niskie wartości wskażników. Procesy depopulacyjne i regres zaludnienia objęły całe terytorium kraju. Nasility się w efekcie emigracji zagranicznej ludzi młodych. Wpłynęło to w konsekwencji negatywnie na strukturę wiekową ludności. Sukcesywnie z roku na rok zmniejszało się zaludnienie kraju. Z punktu widzenia etnicznego przemiany te miały charakter selektywny. Dotyczyły bardziej mniejszości narodowościowych niż rdzennych Łotyszy. Ci ostatni byli bardziej emocjonalnie związani z państwem, mniej wyobcowani z otoczenia i preferowani przez władze. Ludność rodowodu rosyjskiego o słabej znajomości języka łotewskiego była bardziej mobilna migracyjnie. Władze łotewskie, zdając sobie sprawę z niskiego i malejącego potencjału demograficznego kraju i małej liczebności własnego narodu, sprzyjały procesom asymilacyjnym i faworyzowały obywateli, którzy deklarowali swoją wierność wobec pryncypiów narodowych i lojalność wobec państwa, w którym zamieszkali.

Ze względu na wage problematyki etnicznej służby statystyczne Łotwy monitorowały skład narodowościowy i corocznie publikowały ściste informacje o zmianach w tym zakresie w skali kraju i poszczególnych prowincji. Dane te miały charakter szacunkowy, ale były wyliczane w sposób dokładny i w miarę wiarygodny. Brano pod uwagę stopę urodzeń, zgonów oraz bilans migracyjny. Najbardziej aktualne dane statystyczne odnoszą się do 2014 roku. Zostaną one przytoczone i poddane wstępnej interpretacji. Według tej oficjalnej dokumentacji liczba ludności Republiki Łotewskiej na początku 2014 roku wynosiła 2001,5 tys. Uległa obniżeniu od 2000 roku o 375,9 tys. i przewiduje się, że jeszcze w tym roku będzie wynosiła poniżej 2,0 mln. Podany regres demograficzny jest niezmiernie wysoki i niepokojący. Nic więc dziwnego, że jest traktowany w Łotwie bardzo poważnie, a nawet pojawiają się opinie o zbliżającej się katastrofie demograficznej. W analizowanym okresie lat 2000-2014 struktura narodowościowa państwa łotewskiego ulegała stopniowej ewolucji. Wykazały to dane statystyczne określone dla tego najbardziej aktualnego przekroju czasowego, tzn. 2014 roku (Latvijas Statisticas Gadagrămata, 2014):

\section{Tabela 7}

\begin{tabular}{|l|c|c|}
\hline \multicolumn{1}{|c|}{ Narodowość } & Liczba w tys. & \% ogółu ludności \\
\hline Łotysze & 1229,1 & 61,4 \\
\hline Rosjanie & 520,1 & 26,0 \\
\hline Białorusini & 69,0 & 3,4 \\
\hline Ukraincy & 65,3 & 3,3 \\
\hline
\end{tabular}




\begin{tabular}{|l|r|r|}
\hline Polacy & 43,4 & 2,2 \\
\hline Litwini & 25,0 & 1,2 \\
\hline Żydzi & 5,4 & 0,3 \\
\hline Niemcy & 2,9 & 0,2 \\
\hline Inne narodowości & 41,3 & 2,0 \\
\hline Razem & 2001,5 & 100,0 \\
\hline
\end{tabular}

W miarę upływu lat okres sowiecki stawał się zaszłością historyczną. Młode pokolenia żyjące już w odmiennych warunkach, bez względu na to, jaką reprezentowały narodowość, przyjmowały nową rzeczywistość jako fakt oczywisty. Dotyczyło to z małymi wyjątkami ludności rosyjskojęzycznej, która musiała się dostosować do pewnej dyskryminacji politycznej i społecznej ${ }^{12}$. Kierunek przemian był już utrwalony i zmiany w składzie narodowościowym państwa tę ewolucję oddawały w sposób wierny. Między 2000 a 2014 rokiem udział ludności narodowości łotewskiej wzrósł z 57,6 do 61,4\%, czyli o 3,8 pkt. procentowego, zaś rosyjskiej zmalał z 29,6 do 26,0\%, czyli o 3,6 pkt. procentowego. Ta przemiana w liczbach względnych nie była duża, ale świadczyła o wyraźnie zaznaczonych tendencjach przeobrażeń, w dodatku w wartościach absolutnych była bardziej wyrazista. W rozpatrywanym okresie 14 lat liczebność ludności rosyjskiej zmalała z 703,2 tys. do 520,1 tys., czyli o 183,1 tys. Ludność narodowości łotewskiej też podlegała depopulacji, ale skala tego procesu w wartościach absolutnych i procentowych była znacznie niższa. Regres demograficzny objął wszystkie mniejszości narodowe. Odniosły się te negatywne uwarunkowania społeczno-psychologiczne, również do ludności polskiej, której liczba obniżyła się między 2000 a 2014 rokiem z 59,5 tys. do 43,4 tys. Trudno ocenić, w jakim stopniu ta informacja statystyczna jest prawdziwa.

Poddane analizie przemiany demograficzno-etniczne w skali całego kraju miały swoją specyfikę regionalną. We wszystkich prowincjach, na które podzielona jest Łotwa, pewne ogólne tendencje były do siebie zbliżone. Wzrastał udział ludności łotewskiej, zaś malał odsetek ludności rosyjskojęzycznej, w tym Rosjan. We wszystkich prowincjach z wyjątkiem Łatgalii i miasta Rygi zdecydowanie dominowała już ludność narodowości łotewskiej. Można podać na przykład proporcje między liczebnością Łotyszy i Rosjan w najważniejszych prowincjach łotewskich. W regionie kurlandzkim w 2014 roku: Łotyszy było - 196,0 tys., zaś Rosjan - 37,0 tys., w regionie liwlandzkim :Łotyszy - 174,3 tys., Rosjan - 18,4 tys., w regionie semigalskim: Łotyszy - 172,1 tys., Rosjan $-42,5$ tys. Nadal bardzo złożona była sytuacja w przygranicznej Łatgalii, która zachowała oblicze polietniczne o niewielkiej względnej dominacji ludności totewskiej. W regionie tym skupiającym w 2014 roku 286,2 tys. mieszkańców, Łotyszy było: - 129,7 tys., Rosjan - 107,3 tys., Polaków - 19,1 tys., Białorusinów - 15,2 tys. Łącznie trzy narody słowiańskie przeważały nad ludnością łotewską. Jeszcze bardziej niekorzystna dla Łotyszy była sytuacja w stolicy Łatgalii - Dyneburgu. W mieście tym liczącym w 2014 roku - 87,4 tys. mieszkańców: Rosjan było - 43,9 tys., Polaków - 12,2 tys., Białorusinów - 6,9 tys., zaś Łotyszy zaledwie 165 tys., czyli stanowili oni zaledwie 18,9\% ludności (Latvijas Statisticas Gadagrămata, 2014).

Ważnym problemem politycznym, który gwarantował przyszłą stabilność kraju, było osłabienie pozycji demograficznej ludności rosyjskiej w stołecznej Rydze. Wiadomo było, że lojalność niektórych mieszkańców narodowości rosyjskiej lub z nią się utożsamiających

12 Nie zmienia to faktu, że współczesna Łotwa jest państwem praworządnym i demokratycznym (Kierończyk, 2008). 
jest bardzo problematyczna i może być wykorzystana przez władze Federacji Rosyjskiej. Dane spisu sowieckiego z końca lat 80. XX wieku ujawniły, że łącznie ludność rosyjska, ukraińska i białoruska r. licząc 517,8 tys. obejmowała 56,9\%, zaś łotewska - 36,5\% zaludnienia miasta. Dla obserwatora zewnętrznego stolica Łotewskiej SRR przypominała wówczas typowe miasto rosyjskie, gdyż dominował w niej język rosyjski. Dlatego też aktualne wyniki z 2014 roku są bardzo ważne, gdyż mogą ujawnić skalę zachodzących w ciągu 24 lat procesów derusyfikacyjnych. Ostatecznie dane szacunkowe odnotowały w mieście liczącym w 2014 roku 643,4 tys. mieszkańców strukturę narodowościową nadal niezmiernie zróżnicowaną ale o wyraźnie zmienionych proporcjach w stosunku do tych, jakie istniały w 1989 roku. Wykazano w nich, że ludność narodowości łotewskiej liczy - 294,0 tys. (45,7\% ogólnego zaludnienia), rosyjskiej - 246,1 tys. (38,2\%), białoruskiej - 25,6 tys. $(4,0 \%)$ i ukraińskiej 22,5 tys. (3,5\%). W stosunku do 1989 roku odsetek ludności łotewskiej zwiększył się o 9,4 pkt. procentowego, zaś łączny udział ludności rosyjskiej, białoruskiej i ukraińskiej obniżył się o 9,3 pkt. procentowego. Na miejsce znacznej przewagi ludności rosyjskojęzycznej, pochodzenia słowiańskiego, mamy już do czynienia z arytmetyczną równowagą, która już wiadomo, będzie ulegała w miarę czasu zmianom na korzyść ludności łotewskiej. Nie tylko ważne są tu demograficzne wyliczenia statystyczne, gdyż pozycja mieszkającej w Rydze ludności narodowości łotewskiej jest politycznie znacznie ważniejsza, gdyż w jej interesie będą działały władze administracyjne wszelkich szczebli. Uzyskanie zaś niebawem przewagi demograficznej przez ludność łotewską w stolicy uprawomocni jej supremacje w wymiarze politycznym i prestiżowym. Nie znaczy to, że się uda całkowicie zmarginalizować ludność o sympatiach prorosyjskich. Niemniej, jej działania destabilizujące będą w miarę czasu mniej skuteczne i spektakularne.

Analiza przemian demograficzno-etnicznych zachodzących na ziemi totewskiej objęła blisko 120 lat. W ciągu tych lat zmieniała się sytuacja geopolityczna i status polityczny mieszkańców. Naród totewski pomimo niewielkiego potencjału demograficznego i wyjątkowo niesprzyjających okoliczności przetrwał i posiada obecnie własne państwo narodowe. Zmieniała się struktura etniczna kraju. Przed stu laty istniała dobrze zorganizowana i kultywująca swoje długoletnie tradycje historyczno-kulturowe bogata mniejszość niemiecka i żydowska. Zostały one w całości unicestwione. Mniej dramatyczne, ale też tragiczne były losy miejscowych Polaków. Na ich miejsce pojawiła się liczna rzesza migrantów rosyjskojęzycznych o rodowodzie i mentalności sowieckiej. Polietniczność uległa przeobrażeniom, ale dalej jest cechą znamienną tego niewielkiego kraju położonego nad Bałtykiem, który nie mógł być ze względu na swoją wielkość pełnoprawnym podmiotem polityki europejskiej.

\section{BIBLIOGRAFIA}

Buczyński, M. (1993). Recepcja łotewskich nazw geograficznych w języku polskim. W E. Walewander (Red.), Polacy na Łotwie (ss. 103-112). Lublin: Katolicki Uniwersytet Lubelski.

Certurtă Tauta Skaitisana Latvija. (1937). Riga. 
Ciesielski, S., Hryciuk, G., \& Srebrakowski, A. (2004). Masowe deportacje ludności w Związku Radzieckim. Toruń: Wydawnictwo Adam Marszałek.

Cynarski, J. (1925). Łotwa współczesna. Warszawa: Biuro Społeczno-Literackie.

Eberhardt, P. (1998). Problematyka narodowościowa Łotwy. Warszawa: Instytut Geografii i Przestrzennego Zagospodarowania PAN. (Zeszyty IGiPZ PAN, 54)

Eberhardt, P. (2012). Przemiany narodowościowe w Łatgalii. Sprawy Narodowościowe, 2012(40), 63-86.

Itogi vsesoiuznoi perepisi naseleniia. (1963). Moskva: Goskomstat.

Kierończyk, P. (2008). Państwo łotewskie: Geneza i ustrój konstytucyjny. Gdańsk: Wydawnictwo Gdańskiej Wyższej Szkoły Administracji.

Korzeń, J. [J. Roszkowski]. (1987). Dramat narodów battyckich. Warszawa: Wydawnictwo Pokolenie.

Latvijas Statisticas Gadagrămata. (2014). Riga: Latvijas Republicas Centrala Statisticas Parvalde.

Łossowski, P. (1990). Łotwa nasz sąsiad: Stosunki polsko-łotewskie. Warszawa: Wydawnictwo Mozaika.

Maliszewski, E. (1922). Polacy na Łotwie. Warszawa: Towarzystwo Straży Kresowej.

Manteuffel, G. (2007). Zarysy z dziejów krain dawnych inflanckich; czyli Inflant właściwych (tak szwedzkich jak i polskich), Estonii z Ozylią, Kurlandii i Ziemi Pilityńskiej. Kraków: Universitas.

Natsional'nyĭ sostav naseleniia. (1991). Moskva: Goskomstat SSSR.

Otra Tauta Skaitisana Latvija. (1930). Riga: Valts Statistika Parvalde.

Paluszyński, T. (1999). Walka o niepodległość Łotwy: 1914 - 1921. Warszawa: Bellona.

Pervaia vseobshchaia perepis' naseleniia Rossiľskoì Imperii (1897 god). (1899-1905). Sankt Petersburg.

Pietkiewicz, K. (1967). Etnografia Łotwy (kultura materialna). Wrocław: Polskie Towarzystwo Ludoznawcze.

Różycki, J. (1930). Polacy na Łotwie. Warszawa: Wydawnictwo im. A. Mickiewicza.

Sworakowski, W. (1934). Polacy na Łotwie. Warszawa: Instytut Badań Spraw Narodowościowych.

Topij, A. (1998). Mniejszość niemiecka w Łotwie i Estonii 1918-1939/1941. Bydgoszcz: Wyższa Szkoła Pedagogiczna. 